\title{
VARIASI PERBANDINGAN TEPUNG TERIGU \\ DAN MOCAF (MODIFIED CASSAVA FLOUR) \\ DALAM PEMBUATAN MIE MOCAF
}

\section{VARIATION OF WHEAT FLOUR AND MOCAF (MODIFIED CASSAVA FLOUR) TO THE MOCAF NOODLES QUALITY}

\author{
Agusri Ramadhan ${ }^{1)}$, Eva Ramalia Sari ${ }^{1)}$ \\ 1) Program Studi Teknologi Pertanian Fakultas Pertanian \\ Universitas Dehasen Bengkulu
}

\begin{abstract}
ABSTRAK
Indonesia memiliki masyarakat yang gemar mengkonsumsi mie, secara umum pembuatan mie menggunakan bahan dasar tepung terigu. Akan tetapi indonesia merupakan negara tropis sehingga budidaya gandum sedikit menjadi kendala sehingga harus di impor dari luar negeri. Karena itu banyak diciptakan produk-produk mie dari bahan campuran pendamping tepung terigu dan salah satunya adalah mie dari Mocaf (Modified cassava flour).

Penelitian ini menggunakan Rancangan Acak Lengkap dengan menggunakan tepung mocaf yang melalui proses fermentasi dengan Starter Bimo-CF selama 12 jam terhadap lima variasi perbandingan tepung terigu dan tepung mocaf yaitu (750gr : 250gr), (600gr : $400 \mathrm{gr})$, (500gr : 500gr), (400gr: 600gr), (750gr : 250gr) dalam pembuatan mie mocaf. Adapun analisa pada penelitian ini meliputi uji elastisitas dan uji organoleptik mie mocaf berdasarkan parameter warna, aroma, rasa dan kekenyalan.

Dari hasil penelitian analisa keragaman terhadap elastisitas dan analisa keragaman terhadap variabel organoleptik mie mocaf menunjukkan bahwa tepung terigu dan tepung mocaf dengan perbandingan $750 \mathrm{gr}$ tepung terigu : 250gr tepung mocaf dari segi elastisitas adalah yang paling elastis dengan waktu putus 51,33 detik dan dari parameter warna, rasa, aroma dan kekenyalan adalah yang paling disukai panelis.
\end{abstract}

Kata kunci : Mie mocaf, tepung terigu, tepung mocaf

\begin{abstract}
Indonesia has people who love to eat noodles, noodle making in general using the basic ingredients of flour. But Indonesia is a tropical country so that the cultivation of wheat a little into obstacles that must be imported from abroad. Because it created a lot of noodle products made from flour mixture companion and one of them is the noodle of Mocaf (Modified cassava flour).

This study uses a completely randomized design using mocaf flour is fermented with starter Bimo-CF for 12 hours to five ratio variation flour and mocaf namely (750gr: 250gr), (600gr: 400gr), (500gr: 500gr), (400gr: 600gr), (750gr: 250gr) in the manufacture of noodles mocaf. The analysis in this study include testing the elasticity and noodles mocaf organoleptic parameters based on color, aroma, flavor and firmness.

The results showed that the elasticity analysis of diversity and variability analysis of the variables showed that the organoleptic mocaf noodle flour and mocaf with 750gr flour ratio: 250gr flour mocaf in terms of elasticity is most elastic with a time of 51.33 seconds and a drop of color parameters, flavor, aroma and firmness are the most preferred panelists.
\end{abstract}

Keywords: Mocaf Noodle, wheat flour, flour mocaf 


\section{PENDAHULUAN}

Mie sudah menjadi seperti makanan kedua setelah nasi. Indonesia memiliki masyarakat yang gemar mengkonsumsi mie dari mie kering sampai mie siap saji secara umum proses pembuatan mie menggunakan bahan dasar tepung terigu yang berasal dari gandum, sedangkan Indonesia adalah negara tropis sehingga budidaya gandum sedikit menjadi kendala dan hingga kini masih sulit untuk menyediakan kebutuhan gandum dari dalam negeri. Gandum termasuk tanaman daerah beriklim dingin (subtropika) yang hingga saat ini hanya mampu ditanam pada dataran tinggi Indonesia, kawasan yang sudah secara komersil mengembangkan gandum tropis adalah Kabupaten Pasuruan di Jawa Timur dan Kabupaten Manggarai di Nusa Tenggara Timur, namun produktivitas per luas lahan belum optimal yaitu berkisar antara 3-4 ton/hektar sehingga untuk memenuhi kebutuhan dalam negeri masih didatangkan dari luar negeri atau impor (Anonim, 2013).

Oleh karena itu banyak diciptakan produkproduk mie dari bahan campuran pendamping tepung terigu, seperti mie hijau yang berasal dari campuran sayursayuran berwarna hijau dan mie dari umbiumbian salah satunya mie dari tepung ubi kayu. Oleh karena itu banyak dilakukan penelitian untuk memperbaiki kualitas dari tepung ubikayu (cassafa) dan dihasilkan tepung ubikayu termodifikasi (mocaf) yang memiliki kualitas lebih baik dari tepung ubikayu (cassafa), dari segi aroma dan derajat keputihannya hampir menyerupai tepung terigu (Buckle, 1987).

Tepung cassava termodifikasi atau dengan nama lain tepung mocaf, adalah produk tepung dari ubikayu yang diproses menggunakan prinsip memodifikasi sel ubikayu secara fermentasi (Jay, 1996). Mikroba yang tumbuh menyebabkan perubahan karakteristik dari tepung yang dihasilkan berupa naiknya viskositas, kemampuan gelatinisasi, daya rehidrasi dan kemudahan melarut (Subagio, 2007). Mikroba juga menghasilkan asam-asam organik, terutama asam laktat dalam bahan dan ketika bahan tersebut diolah akan menghasilkan aroma dan cita rasa khas yang dapat menutupi aroma dan cita rasa ubikayu yang cenderung tidak disukai konsumen (Kuswanto dan Sudarmadi, 1988). Teknologi fermentasi tersebut sangat membantu dalam proses pembuatan produk mie yang berbahan dasar tepung ubikayu sehingga produk akhir dari mie berbahan dasar tepung ubikayu termodifikasi (mocaf) bisa diterima konsumen dan dapat bersaing dipasaran. Tujuan penelitian ini adalah memodifikasi ubikayu dengan metode fermentasi menggunakan stater Bimo-CF yang ditujukan untuk memperbaiki sifat fisikokimia tepung ubikayu yang dapat 
meningkatkan daya elastisitas/kekenyalan mie dalam pembuatan mie mocaf.

\section{METODOLOGI}

\section{Bahan dan Alat}

Bahan yang digunakan dalam penelitian ini adalah ubi singkong Farietas Adira-4 yang diperoleh dari perkebunan petani Desa Cahaya Negeri Bengkulu Selatan, tepung terigu cakra kembar, starter Bimo-CF yang didapat dari Politeknik Tristar Surabaya Indonesia, air, bawang merah, bawang putih, garam, telur dan bubuk soda kue. Adapun alat-alat yang digunakan dalam penelitian ini meliputi : timbangan, kompor, pisau, baskom, dandang, mesin penggiling, mesin pencetak mie, dandang pengukus dan ayakan. Rancangan penelitian yang dilakukan adalah Rancangan Acak Lengkap dengan perlakuan satu faktor yaitu ubikayu yang melalui proses fermentasi Starter Bimo-CF selama 12 jam. Kombinasi Variabel dengan lima faktor beda, yaitu perbandingan tepung terigu dan mocaf $75 \%: 25 \%, 60 \%$ $: 40 \%, 50 \%: 50 \%, 40 \%$ :60\% dan $25 \%$ $: 75 \%$.

\section{HASIL DAN PEMBAHASAN}

\section{Elastisitas Mie Mocaf}

Menurut Astawan (1999), tepung terigu memiliki kemampuan untuk membentuk gluten pada saat tepung terigu dibasahi dengan air. Sifat elastisitas gluten pada adonan mie yang dihasilkan tidak mudah putus pada proses pencetakan dan pemasakan. Jika penggunaan terigu tersebut dikurangi dan diganti dengan penambahan mocaf maka mengakibatkan mie yang dihasilkan mudah putus dan menurunkan penilaian tererhadap elastiisitaas.

Dalam penelitian ini kekenyalan (elastisitas) mie mocaf diketahui melalui akumulasi waktu yang dibutuhkan oleh mie untuk menahan 5,0 gram beban yang diberikan sampai mie tersebut putus. Semakin lama waktu yang dibutuhkan mie untuk menahan beban sampai mie tersebut putus, maka semakin elastis mie yang dihasilkan (Serie, 2012).

Dilihat dari nilai rata-rata waktu putus mie mocaf, menunjukkan perbedaan nyata pada perbandingan tepung terigu dan tepung mocaf $750 \mathrm{gr}$ : 250gr. Hal ini menunjukkan bahwa perbandingan komposisi tepung terigu terhadap tepung mocaf dalam pembuatan mie mocaf dengan berbagai perbandingan komposisi berpengaruh terhadap elastisitas/kekenyalan mie mocaf yang dihasilkan. Untuk melihat nilai ratarata waktu putus mie mocaf berdasarkan penambahan beban tertentu pada berbagai perbandingan komposisi tepung terigu dengan tepung mocaf dapat dilihat pada tabel 1 . 
Tabel 1. Pengaruh Perbandingan Tepung Terigu dan Tepung Mocaf terhadap Rata-rata Waktu Putus Mie Mocaf (detik)

Perbandingan Tepung Terigu Waktu Rata-Rata

\begin{tabular}{cc} 
dan Tepung Mocaf & Putus Mie \\
\hline $750 \mathrm{gr}: 250 \mathrm{gr}$ & $51,33 \mathrm{a}$ \\
$600 \mathrm{gr}: 400 \mathrm{gr}$ & $42,67 \mathrm{~b}$ \\
$500 \mathrm{gr}: 500 \mathrm{gr}$ & $30,67 \mathrm{c}$ \\
$400 \mathrm{gr}: 600 \mathrm{gr}$ & $21,33 \mathrm{~d}$ \\
$250 \mathrm{gr}: 750 \mathrm{~g}$ & $15,33 \mathrm{e}$
\end{tabular}

Ket : Nilai yang diikuti oleh kode huruf yang berbeda menunjukkan adanya perbedaan yang nyata pada tingkat signifikan 5\%

Dari hasil pengujian diatas, diperoleh bahwa nilai rata-rata ranking tertinggi dicapai oleh mie mocaf dengan perbandingan $750 \mathrm{gr}$ tepung terigu dan 250gr tepung mocaf. Mie dengan perbandingan $750 \mathrm{gr}$ tepung terigu dan 250gr tepung mocaf cukup elastisitas dimana waktu putus mie 51,33 detik, yang berbeda nyata dengan seluruh variasi perbandingan tepung yang lainnya. Hal ini dikarenakan kandungan gluten yang dimiliki tepung terigu sangat berpengaruh pada kekenyalan mie tersebut (Rahayu, 2001). Sedangkan tidak terdapatnya kandungan gluten dalam tepung mocaf menyebabkan semakin banyak campuran mocaf pada produk mie akan menghasilkan mie yang memiliki elastisitas yang rendah sehingga mie tersebut bersifat rapuh dan mudah patah.

\section{Sifat Organoleptik Mie Mocaf}

Hasil analisa keragaman terhadap variabel organoleptik menunjukkan bahwa perbandingan komposisi memberikan pengaruh yang nyata terhadap rasa, aroma dan kekenyalan pada tingkat signifikan $5 \%$, berbeda nyata, akan tetapi pada warna tidak berbeda nyata.

Hasil uji Organoleptik mie mocaf menunjukkan bahwa perbandingan tepung terigu dan tepung mocaf dalam pembuatan mie mocaf terbukti mempengaruhi penerimaan panelis terhadap warna, rasa, aroma dan kekenyalan yang dihasilkan, nilai $\mathrm{F}$ hitung pada warna, rasa, aroma dan kekenyalan lebih besar daripada nilai $\mathrm{F}$ tabel, sehingga uji organoleptik terhadap warna, rasa, aroma dan kekenyalan mie mocaf perlu dilakukan uji lanjut. 
Tabel 2. Rekapitulasi Rata-Rata Hasil Uji Organoleptik Perbandingan Tepung Terigu dan Tepung Mocaf dalam Pembuatan Mie Mocaf

\begin{tabular}{ccccc} 
Perbandingan Tepung & \multicolumn{4}{c}{ Atribut Perlakuan } \\
\cline { 2 - 5 } Terigu dan tepung Mocaf & Warna & Rasa & Aroma & Kekenyalan \\
\hline 750gr : 250gr & $2,03 \mathrm{c}$ & $2,03 \mathrm{~d}$ & $2,07 \mathrm{e}$ & $2,03 \mathrm{e}$ \\
600gr : 400gr & $2,07 \mathrm{c}$ & $2,13 \mathrm{c}$ & $2,67 \mathrm{~d}$ & $2,67 \mathrm{~d}$ \\
500gr : 500gr & $2,50 \mathrm{~b}$ & $2,80 \mathrm{~b}$ & $3,07 \mathrm{c}$ & $3,17 \mathrm{c}$ \\
400gr : 600gr & $3,07 \mathrm{ab}$ & $3,17 \mathrm{ab}$ & $3,67 \mathrm{~b}$ & $3,73 \mathrm{~b}$ \\
250gr : 750gr & $3,20 \mathrm{a}$ & $3,87 \mathrm{a}$ & $4,00 \mathrm{a}$ & $4,00 \mathrm{a}$
\end{tabular}

Ket : 1.Suka sekali, 2.Suka, 3.Agak suka, 4. Tidak suka, 5. Sangat tidak suka

Nilai yang diikuti oleh kode huruf yang berbeda menunjukkan adanya perbedaan yang nyata pada tingkat signifikan 5\%

\section{Warna}

Menurut Kartika dkk (1998) bahwa uji warna lebih banyak melihat indera penglihatan dan merupakan salah satu indikator untuk menentukan apakah suatu bahan pangan diterima atau tidak oleh masyarakat sebagai konsumen, karena makanan yang berkualitas (rasanya enak, bergizi dan bertekstur baik) belum tentu disukai oleh konsumen jika bahan makanan tersebut memiliki penampilan warna yang tidak menarik dipandang atau menying dari warna aslinya.

Hasil analisa uji warna mie mocaf dengan perbandingan tepung terigu dan tepung mocaf dalam pembuatan mie mocaf menunjukkan perbedaan yang nyata pada perbandingan tepung terigu dan tepung mocaf $750 \mathrm{gr}: 250 \mathrm{gr}$ berbeda nyata.
Nilai rata-rata rangking tertinggi diperoleh pada perbandingan tepung terigu dan tepung mocaf $750 \mathrm{gr}$ : 250gr, yaitu 2,03 (suka) berbeda tidak nyata dengan perbandingan tepung terigu dan tepung mocaf 600gr : 400gr sebesar 2,07 (suka) serta perbandingan tepung terigu dan tepung mocaf 500gr : 500gr sebesar 2,50 (suka). Sedangkan perbandingan tepung terigu dan tepung mocaf 400gr : 600gr sebesar 3,07 (agak suka) berbeda tidak nyata dengan perbandingan tepung terigu dan tepung mocaf $250 \mathrm{gr}$ : $750 \mathrm{gr}$ sebesar 3,20 (agak suka). Hal ini dikarenakan tingkat kecerahan warna putih pada mocaf agak sedikit berbeda dengan tepung terigu,sehingga semakin banyak penambahan mocaf akan semakin membuat warna pada mie berkurang kecerahannya (agak pucat). 
Tabel 3. Nilai Rata-rata Tingkat Kesukaan Panelis terhadap Mie Mocaf Berdasarkan Parameter Warna

\begin{tabular}{l}
\hline Atribut $\quad$ Perbandingan tepung terigu dan tepung mocaf \\
Perlakuan $750 \mathrm{gr}: 250 \mathrm{gr}$ 600gr:400gr 500gr:500gr 400gr:600gr 250gr:750gr
\end{tabular}

\begin{tabular}{llllll}
\hline Warna & $2,03 \mathrm{c}$ & $2,07 \mathrm{c}$ & $2,50 \mathrm{~b}$ & $3,07 \mathrm{ab}$ & $3,20 \mathrm{a}$ \\
\hline
\end{tabular}

Ket : 1.Suka sekali, 2.Suka, 3.Agak suka, 4. Tidak suka, 5. Sangat tidak suka

Nilai yang diikuti oleh kode huruf yang berbeda menunjukkan adanya perbedaan yang nyata pada tingkat signifikan $5 \%$

\section{Rasa}

Menurut Soekarto (1985), bahwa uji rasa banyak melibatkan indera pengecap atau lidah yang dapat mengetahui kelarutan bahan makanan tersebut dalam saliva dan kontak dengan syaraf perasa. Peracikan rasa merupakan suatu segesti kejiwaan seseorang terhadap makanan serta menentukan nilai kepuasan orang yang memakannya. Dengan demikian hasil tersebut semakin memperkuat peluang perbandingan tepung terigu dan tepung mocaf dalam pembuatan mie mocaf $750 \mathrm{gr}$ : 250gr paling disukai oleh masyarakat atau konsumen. Pada mie dengan perbandingan tepung terigu dan tepung mocaf $250 \mathrm{gr}$ : 750 gr rasa ubikayu masih ada sedikit di lidah sehingga panelis sedikit kurang menyukainya.

Hasil analisa untuk uji organoleptik untuk rasa pada mie mocaf menunjukkan perbedaan yang nyata antar perlakuan pada perbandingan tepung terigu dan tepung mocaf $750 \mathrm{gr}: 250 \mathrm{gr}$.
Nilai rata-rata ranking tertinggi diperoleh pada perbandingan tepung terigu dan tepung mocaf $750 \mathrm{gr}$ : 250gr, yaitu 2,03 (suka) berbeda tidak nyata dengan perbandingan tepung terigu dan tepung mocaf 600gr : 400gr sebesar 2,13 (suka) serta perbandingan tepung terigu dan tepung mocaf 500gr : 500gr sebesar 2,80 (suka). Sedangkan perbandingan tepung terigu dan tepung mocaf 400gr : 600gr sebesar 3,17 (agak suka) berbeda tidak nyata dengan perbandingan tepung terigu dan tepung mocaf $250 \mathrm{gr}$ : 750gr sebesar 3,87 (agak suka). Rasa ubikayu pada mocaf setelah melalui proses fermentasi memang sedikit dapat berkurang atau tersamarkan, dengan kata lain masih ada sedikit rasa ubikayu pada mocaf tapi tidak sebesar rasa pada tepung cassava. Sehingga dengan semakin banyak penambahan campuran mocaf akan membuat rasa ubikayu pada mie tersebut akan semakin terasa. 
Tabel 4. Nilai Rata-rata Tingkat Kesukaan Panelis terhadap Mie Mocaf Berdasarkan Parameter Rasa

\begin{tabular}{|c|c|c|c|c|c|}
\hline \multirow{2}{*}{$\begin{array}{c}\text { Atribut } \\
\text { Perlakuan }\end{array}$} & \multicolumn{4}{|c|}{ Perbandingan tepung terigu dan tepung mocaf } \\
\cline { 2 - 6 } & 750 gr:250gr & 600gr:400gr & 500gr:500gr & 400gr:600gr & 250gr:750gr \\
\hline Rasa & $2,03 \mathrm{~d}$ & $2,13 \mathrm{c}$ & $2,80 \mathrm{~b}$ & $3,17 \mathrm{ab}$ & $3,87 \mathrm{a}$ \\
\hline
\end{tabular}

Ket : 1.Suka sekali, 2.Suka, 3.Agak suka, 4. Tidak suka, 5. Sangat tidak suka Nilai yang diikuti oleh kode huruf yang berbeda menunjukkan adanya perbedaan yang nyata pada tingkat signifikan $5 \%$

\section{Aroma}

Hasil analisa uji organoleptik untuk aroma pada mie mocaf menunjukkan perbedaan yang nyata antar perlakuan pada perbandingan tepung terigu dan tepung mocaf $750 \mathrm{gr}: 250 \mathrm{gr}$.

Nilai rata-rata rangking tertinggi diperoleh pada perbandingan tepung terigu dan tepung mocaf $750 \mathrm{gr}$ : 250gr, yaitu 2,07 (suka) berbeda tidak nyata dengan perbandingan tepung terigu dan tepung mocaf 600gr : 400gr sebesar 2,67 (suka). Perbandingan tepung terigu dan tepung mocaf 500gr : 500gr sebesar 3,07 (agak suka) berbeda tidak nyata dengan perbandingan tepung terigu dan tepung mocaf 400gr : 600gr sebesar 3,17 (agak suka) serta berbeda nyata dengan perbandingan tepung terigu dan tepung mocaf 250gr : 750gr sebesar 4,0 (tidak suka). Aroma ubikayu pada mocaf setelah melalui proses fermentasi memang sedikit dapat berkurang atau tersamarkan, dengan kata lain masih ada sedikit aroma ubikayu pada mocaf tapi tidak setajam aroma pada tepung cassava. Sehingga dengan semakin banyak penambahan campuran mocaf akan membuat aroma ubikayu pada mie tersebut akan semakin terasa.

Menurut Winarno (2002), bahwa uji aroma banyak menggunakan indera penciuman, karena kelezatan suatu makanan sangat ditentukan oleh aroma makanan tersebut dan dapat menjadi salah satu indikator penting dalam menentukan kualitas pangan. Umumnya konsumen menyukai aroma aroma khas yang tidak menyimpang dari aroma normal.

Tabel 5. Nilai Rata-rata Tingkat Kesukaan Panelis terhadap Mie Mocaf Berdasarkan Parameter Aroma

\begin{tabular}{|c|c|c|c|c|c|}
\hline \multirow{2}{*}{$\begin{array}{c}\text { Atribut } \\
\text { Perlakuan }\end{array}$} & \multicolumn{4}{|c|}{ Perbandingan tepung terigu dan tepung mocaf } \\
\cline { 2 - 6 } & $750 \mathrm{gr}: 250 \mathrm{gr}$ & $600 \mathrm{gr}: 400 \mathrm{gr}$ & $500 \mathrm{gr}: 500 \mathrm{gr}$ & $400 \mathrm{gr}: 600 \mathrm{gr}$ & $250 \mathrm{gr}: 750 \mathrm{gr}$ \\
\hline Aroma & $2,07 \mathrm{e}$ & $2,67 \mathrm{~d}$ & $3,07 \mathrm{c}$ & $3,67 \mathrm{~b}$ & $4,00 \mathrm{a}$ \\
\hline
\end{tabular}

Ket : 1.Suka sekali, 2.Suka, 3.Agak suka, 4. Tidak suka, 5. Sangat tidak suka Nilai yang diikuti oleh kode huruf yang berbeda menunjukkan adanya perbedaan yang nyata pada tingkat signifikan 5\% 
Tabel 6. Nilai Rata-rata Tingkat Kesukaan Panelis terhadap Mie Mocaf Berdasarkan Parameter Kekenyalan

\begin{tabular}{|c|c|c|c|c|c|}
\hline \multirow{2}{*}{$\begin{array}{c}\text { Atribut } \\
\text { Perlakuan }\end{array}$} & \multicolumn{4}{|c|}{ Perbandingan tepung terigu dan tepung mocaf } \\
\cline { 2 - 6 } & $750 \mathrm{gr}: 250 \mathrm{gr}$ & $600 \mathrm{gr}: 400 \mathrm{gr}$ & $500 \mathrm{gr}: 500 \mathrm{gr}$ & $400 \mathrm{gr}: 600 \mathrm{gr}$ & $250 \mathrm{gr}: 750 \mathrm{gr}$ \\
\hline Warna & $2,03 \mathrm{e}$ & $2,67 \mathrm{~d}$ & $3,17 \mathrm{c}$ & $3,73 \mathrm{~b}$ & $4,00 \mathrm{a}$ \\
\hline
\end{tabular}

Ket : 1.Suka sekali, 2.Suka, 3.Agak suka, 4. Tidak suka, 5. Sangat tidak suka Nilai yang diikuti oleh kode huruf yang berbeda menunjukkan adanya perbedaan yang nyata pada tingkat signifikan $5 \%$

\section{Kekenyalan}

Hasil analisa uji organoleptik untuk parameter kekenyalan pada mie mocaf menunjukkan perbedaan yang nyata antar perlakuan pada perbandingan tepung terigu dan tepung mocaf $750 \mathrm{gr}: 250 \mathrm{gr}$.

Nilai rata-rata rangking tertinggi diperoleh pada perbandingan tepung terigu dan tepung mocaf $750 \mathrm{gr}$ : 250gr, yaitu 2,03 (suka) berbeda tidak nyata dengan perbandingan tepung terigu dan tepung mocaf 600gr : 400gr sebesar 2,67 (suka). Perbandingan tepung terigu dan tepung mocaf 500gr : 500gr sebesar 3,17 (agak suka) berbeda tidak nyata dengan perbandingan tepung terigu dan tepung mocaf 400gr : 600gr sebesar 3,73 (agak suka) serta berbeda nyata dengan perbandingan tepung terigu dan tepung mocaf 250gr : 750gr sebesar 4,0 (tidak suka).

Kandungan gluten yang dimiliki tepung terigu sangat berpengaruh pada kekenyalan (Andini, 2009). Sedangkan tidak terdapatnya kandungan gluten dalam tepung mocaf menyebabkan semakin banyaknya campuran mocaf pada produk maka akan menghasilkan mie yang memiliki elastisitas yang rendah. Oleh karena itu semakin tinggi penambahan tepung mocaf dalam campuran mie akan menghasilkan mie yang bersifat rapuh dan mudah patah sehingga tidak disukai oleh panelis.

\section{SIMPULAN}

Hasil analisa elastisitas secara statistik menunjukkan bahwa mie mocaf dengan perbandingan tepung terigu dan tepung mocaf pada berbagai perbandingan memiliki pengaruh yang nyata. Hasil uji organoleptik berdasarkan parameter warna menunjukkan bahwa mie mocaf dengan perbandingan tepung terigu dan tepung mocaf $750 \mathrm{gr}$ : 250gr berdasarkan parameter warna lebih disukai oleh panelis dibandingkan dengan perlakuan yang lain. Berdasarkan parameter rasa menunjukkan mie mocaf dengan perbandingan tepung terigu dan tepung mocaf 750gr : 250gr berdasarkan parameter rasa lebih disukai oleh panelis 
dibandingkan dengan perlakuan yang lain. Berdasarkan parameter aroma menunjukkan bahwa mie mocaf dengan perbandingan tepung terigu dan tepung mocaf $750 \mathrm{gr}: 250 \mathrm{gr}$ berdasarkan parameter aroma lebih disukai oleh panelis dibandingkan dengan perlakuan yang lain. Berdasarkan parameter kekenyalan menunjukkan bahwa mie mocaf dengan perbandingan tepung terigu dan tepung mocaf $750 \mathrm{gr}$ : 250gr berdasarkan parameter kekenyalan lebih disukai oleh panelis dibandingkan dengan perlakuan yang lain.

\section{DAFTAR PUSTAKA}

Anonim, 2013. Wikipedia Bahasa Indonesia, Ensiklopedia bebas http://id.wikipedia.org/wiki/ubi_k ayu.

Andini, B, 2009, Kandungan Protein Terigu.Http//www.wiki.co.id/gizi/t erigu.

Astawan , Made. 1999. Membuat mie dan Bihun. Penebar Swadaya. Jakarta.

Buckle, K.A. Edward, G.H. Fleet, and M. Wooton 1987, Ilmu Pangan, Universitas Indonesia Press, Jakarta.

Jay, M. James. 1996. Modern Food Microbiology. Fifth edition.
Chapman and Hall. New York, USA.

Kartika, B., P. Hastuti dan W. Supartono. 1998. Pedoman Uji Indrawi Bahan Pangan PAU Pangan PAU Pangan dan Gizi Universitas Gaja Mada, Yogyakarta.

Kuswanto, K.R., dan Slamet Sudarmadji, 1988.

Proses-proses Mikrobiologi Pangan, PAU Pangan dan Gizi Universitas Gajah Mada. Yogyakarta.

Rahayu, R. 2001. Kekenyalan Tepung Terigu. Institut Pertanian Bogor. Bogor.

Serie, Evo T 2012. Pengaruh Penambahan Air Abu Jerami dan Ekstrak Kunyit Terhadap Elastisitas dan Mutu Organoleptik Mie Basah. Skripsi. Fakultas Pertanian, Universitas Dehasen Bengkulu. Bengkulu (tidak dipublikasikan).

Soekarto, S. T. 1985. Penilaian Organoleptik Untuk Industri Pangan dan Hasil Pertanian. Bhatara Karya Aksara. Jakarta.

Subagio A. 2007. Industrialisasi Modified Cassava Flour (MOCAF) sebagai Bahan Baku Industri Pangan untuk Menunjang Diversifikasi Pangan Pokok Nasional. Jember : Fakultas Teknologi Pertanian, Universitas Jember.

Winarno, F. G., 2002. Kimia Pangan dan Gizi. Gramedia Pustaka Uama Jakarta. 